\title{
Chůze v evidenci pohybových aktivit osob se zrakovým postižením
}

\section{Walking in the records of physical activities of people with visual impairments}

\author{
Ladislav Bláha \\ Pedagogická fakulta, Univerzita J. E. Purkyně, Ústí nad Labem, \\ Česká republika
}

\section{Abstrakt:}

Pro osoby se zrakovým postižením $(\mathrm{ZrP})$ je provozování pohybových aktivit v mnoha směrech náročnější. Negativni trendy současného životního stylu spojené s nevyvážeností přijmu a výdeje energie na ně však mohou doléhat ve zvýšené míre. Přiležitostí k energetickému výdeji není príliš mnoho. K nejčastěji udávaným pohybovým aktivitám osob se zrakovým postižením patři chüze. Její realizace může být ale spojena s řadou problémů. Cílem studie bylo zjistit, v jaké míre se realizují objemy každodennich PA ve srovnání s pasívním odpočinkem a jsou tak součástí běžného života u osob se ZrP. Krátkou verzi dotazníku IPAQjsme u občanů se zrakovým postižením (n=152) v Ústeckém kraji zjištovali ukazatele charakterizujicí uplatňované pohybové aktivity a inaktivity během týdne. Ziskaná data byla přepočitána na hodnoty MET a MET-min - týden-1. Na celkovém objemu vykazovaných aktivit během týdne (2 967 MET-min · týden ${ }^{-1}$ ) se značnou mérou podilí chůze (2 222 MET-min · týden ${ }^{-1}$ ). Ziskaná data jsme se pokusili objektivizovat aplikací pedometrü, která ukázala reálně nizké objemy kroků u vybraných jedinců. Ukazuje se, že jen malá část osob se ZrP plní více zdravotně doporučovaných kriterii. Jejich životni styl může trpět přemirou sedavých aktivit, které mohou nepřiznivě ovlivňovat zdraví. Doporučujeme podporovat jejich aktivitu přitomností trasérů, zlepšením v navigaci a př́pravou specifických programů. Opatření vidíme také na úrovni komunální politiky. 


\section{Abstract:}

It is more difficult in many ways to carry out physical activities for people with visual impairments. The negative trends of contemporary lifestyle related to the imbalance of energy intake and expenditure may lie on them in the increased rate. They do not have too many opportunities for the energy expenditure. The most commonly reported physical activities of people with visual impairments include walking. But its realization may be associated with a number of problems. The aim of the study was to find out the volume of everyday physical activities in comparison with the passive relaxation and to find out to which extent they are a part of everyday life of people with visual impairments. We investigated the indicators characterizing the applied physical activity and inactivity during the week among the citizens with the visual impairment in the Usti Region $(n=15)$ using the short version of the IPAQ questionnaire. The acquired data were converted to values MET and MET-min . week $^{-1}$. In the total volume of reported activities during the week (2 967 MET-min - week ${ }^{-1}$ ) there is a big volume of walking (2 222 MET-min . week $\left.{ }^{-1}\right)$. We tried to objectify the acquired data by using pedometers and it showed low volumes of steps for selected individuals. It turns out that only a small proportion of people with visual impairments fulfil more of the medical recommended criteria. Their lifestyle may suffer from an excess of sedentary activities that may adversely affect health. We recommend supporting their activity by the presence of tracers, improvements in navigation and preparation of specific programmes. We also see the arrangements at the level of local politics.

Klíčová slova: pohybové aktivity, inaktivity, lokomoce, osoby s postiženim zraku, dotaznik IPAQ, pedometr.

Key words: physical activity, inactivity, locomotion, people with visual impairments, IPAQ questionnaire, pedometer.

Př́spěvek vznikl za podpory projektu OPVK ESF CZ.1.07/2.2.00/15.0336 „Příprava pro tělesnou výchovu osob s postižením“ a interních grantů PF UJEP v Ústí nad Labem. 


\section{ÚVOD}

Provozování pohybových aktivit (PA) osobami se zrakovým postižením (ZrP) je spojeno s řadou otázek každodenního vykonávání pohybových činností na straně jedné až po možnosti aplikace řízených programů na straně druhé. V centru naší pozornosti by však vždy měla být snaha po uplatňování pohybových aktivit, které vedou ke kultivaci pohybového projevu, přispívají k udržení zdravého životního stylu a zlepšují kvalitu života. Jednou z těchto stále nedoceňovaných aktivit je chůze. Dovednost, kterou si člověk v současné době nedopřává v žádoucí míře. U osob se ZrP se chůze v mnoha směrech jeví jako aktivita nezbytná i z důvodu snížených možností využívat vlastní transportní prostředky pro kontakt se zaměstnáním nebo zajišt'ování př́íslušných potřeb. A nelze opomíjet její zdravotní aspekt, pokud není možné realizovat sportovně orientované aktivity. Zajímalo nás tedy, do jaké míry osoby se ZrP chůzi vykonávají a do jaké míry ji lze sledovat i v souvislosti s běžnou populací.

\section{HLAVNÍ ČÁST}

\section{Teoreticko metodologická východiska}

Osoby se ZrP jsou přes různá opatření, kompenzační mechanismy aj. omezeny $\mathrm{v}$ interakci s prostředím. Lidé s tímto postižením jsou podle doby jeho vzniku stavěni před řadu omezení, které limitují využivání potenciálu spektra schopností a souběžně s tím i osvojování dovedností. Komplexnost problémů spojených s výše zmíněnou interakcí se tak projevuje nižší úrovní pohybových schopností (Hopkins, Gaeta, Thomas, \& Hill, 1987; Lieberman \& McHugh, 2001; Nakamura, 1997; Short \& Winnick, 1988) a promítá se i do vykonávání každodenních činností, výskytu negativních znaků charakterizujících sociální dovednosti a také do dřivějšího nástupu kardiorespiračních onemocnění a obezity (Leverenz, 2009). Již u dětí se ZrP byly konstatovány nižší úroveň schopností a zpoždění ve zvládnutí některých dovedností (Blessing, McCrimmon, Stovall, \& Williford, 1993; Janečka, 2003). Sníženou úrovní rovnováž- 
ných schopností je také výrazně ovlivněna mobilita, která následně limituje spektrum dalších činností. Nižší je také objem času věnovaný PA (Houwen, Hartman, \& Visscher, 2009). Ačkoli byly mezi úrovní PA a indikátory zdraví prokázány vzájemné vazby (Abu-Omar \& Rütten, 2008), zůstává otázkou, zda a jak lze u osob se ZrP intervenovat ve prospěch provozování běžných nebo speciálně uzpůsobených PA (Bláha, 2011), které by vyhovovaly potřebám a možnostem osob se ZrP. Východiskem jsou obecně platné argumenty o podpoře „běžných pohybových aktivit“, které podporují zdravý životní styl, formují pohybové dovednosti a rozšiřují spektrum potřebných znalostí (Abu-Omar, Rütten, \& Robine, 2004; Bauman, Sallis, Dzewaltowski, \& Owen, 2002). Je nutné respektovat, že k samotnému zrakovému postižení se obvykle přidružují jeho průvodní jevy jako obavy ze zranění, neznalost aktivit nebo chybějící dovednosti, pocit zesměšnění, chybějící trasér nebo vodič. Vedle toho také vliv počasí, chybějící psychická podpora z okolí a motivace, pocit zbytečnosti, rezignace, lenost a svoji roli hraje i samotná nadváha. Naše studie uvádějí také potřebu pasívního odpočinku vyvolanou potřebou „uvolnění“ po stálém zaměřování pozornosti spojenou s orientováním se v prostoru (Bláha, 2011). Je zřejmé, že v souvislosti s provozováním PA musíme řešit řadu vzájemně provázaných proměnných. Za hlavní provázané okruhy považujeme zvyšování úrovně pohybových schopností, podmínky a možnosti provozování PA. Chůze jako nejčastěji uplatňovaná a zároveň dostupná PA tu zaujímá významné místo. Potvrdit by nám to měla aplikace pedometrů. Ale dosavadní šetření ukázala sníženou úroveň ukazatelů ve srovnání s lidmi běžné populace (Lieberman, Stuart, Hand, \& Robinson, 2006) a nižší úroveň v objemu kroků u dívek ve srovnání s chlapci se ZrP (Lieberman \& McHugh, 2001). Při hodnocení chůze lze vycházet z dlouhodobých sledování, která tvrdí, že zdraví dospělí by měli absolvovat 7 000-13 000 kroků denně (ženy méně než muži), zdraví starší lidé: 6 000-8 500 kroků a lidé se zdravotními omezeními (u kterých zdravotní omezení staví limity ve smyslu funkčního zatížení organismu při uplatnění chůze): 3 500-5 500 kroků (Tudor-Locke \& Myers, 2001). Podobným způsobem lze uplatnit GPS zařízení, kte- 
ré pomůže zpřesnit některé parametry této lokomoce a poukáže i na shodu nebo nesoulad vykazovaných hodnot různými výzkumnými nástroji. Cílem studie bylo zjistit, v jaké míre se realizují objemy každodenních PA ve srovnání s pasívním odpočinkem a jsou tak součástí běžného života osob se ZrP. Chceme také přispět ke zpřesňování údajů ze specifického charakteru lokomoce osob se ZrP a poukázat možnosti jejich dalšího sledování.

\section{CHARAKTERISTIKA SOUBORU}

Šetření se zúčastnili klienti Tyflocentra v Ústí nad Labem (tab. 1). Respondenti $(\mathrm{n}=152)$ vykazovali stupně postižení podle sportovní klasifikace IBSA (International Blind Sport Federation), kdy B1 vyjadřuje nejtěžší stupeň $\mathrm{ZrP}$ (prakticky nevidomost) až B3 - nejnižší stupeň ZrP. Vybraná data jsme srovnávali s členy běžné populace (BP) stejného regionu $(\mathrm{n}=2177)$. Šetření s pedometry se zúčastnilo 35 osob se $\mathrm{ZrP}$ (úspěšně dokončilo 13 mužů a 17 žen). Nasazení GPS zařízení doplněné sportestery bylo řešeno jako prŕípadové studie na šesti osobách se ZrP různého věku.

Tab. 1: Soubory respondentů se zrakovým postižením podle stupně postižení

\begin{tabular}{|c|c|c|c|c|c|c|c|c|c|}
\hline \multicolumn{2}{|c|}{ Respondenti } & \multicolumn{2}{|c|}{ věk } & \multicolumn{2}{c|}{ výška } & \multicolumn{2}{c|}{ hmotnost } & \multicolumn{2}{c|}{ BMI } \\
\hline & $\mathrm{n}$ & $\mathrm{M}$ & $\mathrm{SD}$ & $\mathrm{M}$ & $\mathrm{SD}$ & $\mathrm{M}$ & $\mathrm{SD}$ & $\mathrm{M}$ & $\mathrm{SD}$ \\
\hline B1 & 71 & 51,37 & 11,71 & 168,66 & 9,16 & 81,59 & 13,10 & 28,84 & 5,24 \\
\hline B2 & 29 & 48,52 & 9,70 & 169,55 & 11,70 & 74,31 & 11,25 & 25,92 & 3,78 \\
\hline B3-4 & 52 & 41,25 & 12,74 & 169,48 & 9,92 & 72,98 & 12,75 & 25,37 & 3,79 \\
\hline
\end{tabular}

Vysvětlivky: Výška (cm); hmotnost $(\mathrm{kg}) ; B M I(\mathrm{~kg} \bullet \mathrm{m}-2) ; M$ - průměr; $S D$ - standardni odchylka 


\section{METODY A ZPRACOVÁNÍ DAT}

Pohybová aktivita byla odhadována na základě krátké administrativní verze dotazníku IPAQ (Epidemiology Unit, University of New South Wales, Sydney). Byl aplikován jako jednoduchá diagnostická technika pro zjištění základních údajů o PA a inaktivitách u běžné populace i osob se ZrP v Ústeckém kraji. IPAQ-short zachycuje PA a inaktivitu 15-69leté populace realizovanou $\mathrm{v}$ posledních sedmi dnech a umožňuje srovnávat PA vysoké a střední intenzity, chůzi a sezení v kontextu s dalšími osobními, demografickými a environmentálními údaji. Vybrané položky vztahující se k hodnocení aplikace PA různé intenzity a chůze byly převedeny na hodnoty MET a MET-min · týden ${ }^{-1}$ (Ainsworth et al., 2000) a získali jsme tak komplexnější obraz o zatížení jednotlivců i charakteristice šetřených souborů. Díky těmto přepočtovým koeficientům bylo možné uplatnit kategoriální tř́ídění jednotlivců na osoby málo aktivní, stř̌edně nebo vysoce aktivní. Zpracováním položek dotazníku byl charakterizován týdenní objem intenzivních pohybových aktivit (dále také VPA), středně zatěžujících aktivit (dále také MPA), chůze a celkové úrovně pohybových aktivit (dále také TPA). Vycházeli jsme z Manuálu pro zpracování a analýzu dat Mezinárodního dotazníku pohybové aktivity (IPAQ) - krátká a dlouhá verze (IPAQ, 2005). Data byla statisticky ošetřena v programu STATISTICA 08 př́śslušnými testy Mann-Whitney a Kruskall-Wallis a umožnila také v kontextu vykazovaných inaktivit zohlednit respektování kritérií zdravotních doporučení. Vybraní probandi $(\mathrm{n}=35)$ používali v klimaticky neutrálních obdobích po dobu osmi dnů (vždy dva víkendové a 5-6 pracovních) pedometry (Yamax Digiwalker SW-700). K těmto osobám patřili především klienti Tyflocenter v Ústí nad Labem a v Karlových Varech, kterým šetření bylo nabídnuto prostřednictvím školených spolupracovníků. Aplikace pedometrů byla náročnější, pokud probandi neměli možnost z důvodu postižení zaznamenávat a kontrolovat hodnoty pedometru. Nošení pedometrů se v těchto prŕípadech omezilo na 8 dní. U vybraných osob došlo k souběžné aplikaci pedometrů a GPS zařízení (Mikoláš, 2013). 


\section{VÝSLEDKY}

Ve vykazovaných PA během jednoho týdne u respondentů se $\mathrm{ZrP}$ chůze dominuje, přičemž vykazované hodnoty lze z časového hlediska považovat za uspokojivé. Účast na intenzivních PA se ukázala velmi nízká, mírné zlepšení bylo zaznamenáno u 30 minut středně zatěžující aktivity v týdnu (53\% respondentů) a v opakované chůzi během týdne (80 \%). Ve vykazované chůzi po dobu minimálně 30 minut dosahuje jejich účast vysoké úrovně (97 \%). Nízké hodnoty vykazují ve srovnání s BP v intenzivních pohybových aktivitách, nižší hodnoty ve středně zatěžujících aktivitách a tím i celkových pohybových aktivitách. Osoby se ZrP vykazují tak nízké hodnoty v intenzivních a středně zatěžujících aktivitách, že také ukazatelé celkových pohybových aktivit jsou nižší (tab. 2).

Tab. 2: Ukazatele absolvované pohybové aktivity u respondentů běžné populace a respondentů se zrakovým postižením

\begin{tabular}{|c|c|c|c|c|c|c|c|c|c|c|}
\hline & \multicolumn{3}{|c|}{$\begin{array}{c}\text { Respondenti bežné } \\
\text { populace } \\
\text { Ukazatel }\end{array}$} & \multicolumn{3}{|c|}{$\begin{array}{c}\text { Respondenti se zrakovým } \\
\text { postižením } \\
\text { (n=152) }\end{array}$} & \multicolumn{3}{c|}{} & \\
\hline & M & SD & Mdn & IQR & M & SD & Mdn & IQR & U & d \\
\hline $\begin{array}{c}\text { VPA/den } \\
\text { (min) }\end{array}$ & 121 & 156 & 51 & 206 & 8 & 34 & 0 & 0 & & \\
\hline VPA & 847 & 1091 & 360 & 1440 & 59 & 239 & 0 & 0 & $11,568^{*}$ & 0,479 \\
\hline $\begin{array}{c}\text { MPA/sum } \\
\text { (min) }\end{array}$ & 240 & 301 & 120 & 360 & 171 & 269 & 60 & 240 & & \\
\hline $\begin{array}{c}\text { MPA/den } \\
\text { (min) }\end{array}$ & 34 & 43 & 17 & 51 & 24 & 38 & 9 & 34 & & \\
\hline MPA & 961 & 1130 & 480 & 1440 & 685 & 1077 & 240 & 960 & $3,916^{*}$ & 0,162 \\
\hline $\begin{array}{c}\text { Chůze/ } \\
\text { sum (min) }\end{array}$ & 633 & 545 & 420 & 870 & 673 & 549 & 480 & 600 & & \\
\hline $\begin{array}{c}\text { Chůze/den } \\
\text { (min) }\end{array}$ & 90 & 78 & 60 & 124 & 96 & 78 & 69 & 86 & & \\
\hline Chůze & 2088 & 1798 & 1386 & 2871 & 2222 & 1812 & 1584 & 1980 & 1,587 & 0,066 \\
\hline TPA & 3896 & 2716 & 3426 & 3972 & 2967 & 2506 & 2111 & 2766 & $4,489^{*}$ & 0,186 \\
\hline
\end{tabular}


Vysvětlivky:

VPA/den - korigovaná průměrná denní doba věnovaná intenzivním pohybovým aktivitám v minutách;

VPA - hodnoty absolvované intenzivni pohybové aktivity za týden vyjádřených v METminutách za týden (v MET-min • týden $\left.{ }^{-1}\right)$;

MPA/sum - celkový objem absolvované středně zatěžujici pohybové aktivity za týden vyjádřených v minutách;

MPA/den - průměrná denní doba věnovaná středně zatěžujícím pohybovým aktivitám $v$ minutách;

MPA - hodnoty absolvované středně zatěžujici pohybové aktivity za týden vyjádřených $v$ MET-min $\bullet$ týden $^{-1}$;

Chůze/sum - celkový objem absolvované chůze za týden vyjádřených v minutách;

Chůze/den - prưměrná denní doba věnovaná chi̊zi v minutách;

Chuze - hodnoty absolvované chůze za týden vyjádřených v MET-min • týden ${ }^{-1}$;

TPA - součet absolvovaných aktivit za týden vyjádřenýv MET-min • týden ${ }^{-1}$;

$M$ - průměr; SD - standardni odchylka; Mdn-medián; IQR - interkvartilové rozpěti; $U$ - hodnota Mann $\neg$-Whitneyova testu; $d$-vypočitaná hodnota koeficientu věcné významnosti; * - u označených testủ byly zjištěny statisticky významné hodnoty na hladině $p<0,05$.

Aplikace pedometrů však ukázala, že i přes časově značné objemy vykazované chůze není ve skutečnosti množství absolvovaných kroků vysoké. Námi zjištěné hodnoty nedosahují úrovně denního objemu kroků běžné populace (Tudor-Locke \& Myers, 2001). Ukázalo se, že muži se ZrP překonávají v denním objemu absolvovaných kroků ženy (tab. 3) nejen $\mathrm{v}$ pracovních dnech $\left(\mathrm{M} \mathrm{ZrP}=4918 \mathrm{krok} \cdot \mathrm{den}^{-1}, \breve{Z} \mathrm{ZrP}=4820\right.$ $\left.\mathrm{krok} \cdot \mathrm{den}^{-1}\right)$, ale i během dnů víkendových $\left(\mathrm{M} \mathrm{ZrP}=4457 \mathrm{krok} \cdot \mathrm{den}^{-1}\right.$, $\left.\check{Z} \mathrm{ZrP}=3853 \mathrm{krok} \cdot \mathrm{den}^{-1}\right)$. U probandů obou souborů se $\mathrm{ZrP}$ rozdíly v absolvované lokomoci existují. Aplikace testu Mann Whitney (stanoveno $\mathrm{z}$ mediánů souborů $\mathrm{M} \mathrm{ZrP} \mathrm{Mdn}=4482 \mathrm{krok} \cdot \operatorname{den}^{-1} \mathrm{a} \check{Z} \mathrm{ZrP}_{\mathrm{Mdn}}=4$ $033 \mathrm{krok} \cdot \mathrm{den}^{-1}$ ) však ukázala, že mezi soubory mužů a žen se ZrP nejsou ve sledovaných parametrech denně absolvovaných kroků během 
týdne ( $\left.\mathrm{krok} \cdot \mathrm{den}^{-1}\right)$ statisticky významné rozdíly (Mann Whitneyův test $\mathrm{U}=0,069 ; \mathrm{p}<0,05)$ a koeficient věcné významnosti je rovněž nízký $(d=0,15)$. Měření za pomoci GPS potvrdilo skutečnost proměnlivého charakteru chůze osob se ZrP. Skutečná délka kroků byla výrazně nižší než obvykle nastavovaná, ale za přítomnosti traséra došlo k jejímu výraznějšímu prodloužení.

Tab. 3: Objemy absolvovaných kroků soubory šetřených mužů a žen se zrakovým postižením

\begin{tabular}{|c|c|c|c|c|c|c|c|}
\hline \multirow{2}{*}{ Soubory } & \multicolumn{6}{|c|}{$\begin{array}{c}\text { Ukazatelé lokomoce u souborů se zrakovým } \\
\text { postižením }\end{array}$} \\
\cline { 2 - 8 } & \multicolumn{2}{|c|}{ Pracovní dny } & \multicolumn{2}{c|}{ Vikendové dny } & \multicolumn{2}{c|}{ Celý týden } \\
\cline { 2 - 8 } \multicolumn{2}{|c|}{} & $\mathrm{M}$ & $\mathrm{SD}$ & $\mathrm{M}$ & $\mathrm{SD}$ & $\mathrm{M}$ & SD \\
\hline $\mathrm{MZrP}$ & 3 & 4918 & 2658 & 4457 & 3293 & 4796 & 2314 \\
\hline ŽZrP & 7 & 4820 & 2371 & 3853 & 3094 & 4505 & 1809 \\
\hline
\end{tabular}

Vysvětlivky:

$M Z r P \quad$-muži se zrakovým postižením;

$\check{Z} \mathrm{ZrP}-$ ženy se zrakovým postiženim;

$n$-počet; $M$ - prüměr; $S D$ - směrodatná odchylka; hodnoty jsou uvedeny v absolvovaných krocich za jeden den (kroky $\bullet$ den $\left.{ }^{-1}\right)$.

\section{DISKUSE}

Chodecké aktivity (2 222 MET-min · týden ${ }^{-1}$ ) osob se ZrP se významně podílejí na celkové PA a jsou plně v relaci s obecnou populací jak v objemu času, tak z toho vyvozené zátěže v MET-min · týden ${ }^{-1}$. Podle našeho názoru jsou na první pohled dobrá data o chůzi také odrazem nevyužívání vlastních dopravních prostředků (auta, kola) a délka trvání chůze je důsledkem specifického zpo̊sobu lokomoce (Bláha \& Cihlár, 2010). Tato skutečnost vyvolává řadu otázek. Tou hlavní je kvalita chůze 
a intenzita zatížení spojená s chůzí. Ukazuje se, že doba strávená chůzí poskytuje spíše obecná data, ale ve smyslu sledování zatížení (zejména s obecnou populací) je nutné zvažovat upřesňování dalšími technikami. Lokomoce osob se ZrP je obvykle pomalejší a pro řešení problémů s orientací je absolvovaná vzdálenost při stejném nebo menším počtu kroků (nejistota v chůzi nutí vzdálenost kroku zkracovat) menší. Dá se ale obtížně hodnotit, do jaké míry je individuálně rozdílně spojena s pozorností a psychickou zátěží, a tím i energetickým výdejem. Chůze se ovšem jeví jako potenciálně jediné větší tělesné zatížení organismu u osob se ZrP. A to navzdory nízkým naměřeným hodnotám $\mathrm{z}$ aplikace pedometrů i GPS. Zvláště při takto nízkých hodnotách nedokáže nahradit ani ve smyslu intenzity ani v objemu výpadek, který je spojen s neuplatňováním intenzivních PA a středně zatěžujících aktivit. Celkový energetický výdej je tak poměrně nízký (Bláha, 2011) a vyvolává řadu otázek souvisejících se zdravým životním stylem.

\section{ZÁVĚR}

Chůze je ze sledovaných ukazatelů nejčastěji uplatňovanou PA $\mathrm{u}$ osob se ZrP. Hodnotami chůze jsou respondenti se ZrP (2 222 METmin $\cdot$ týden $^{-1}$ ) srovnatelní se zástupci běžné populace. Nedostatek uplatňování intenzivních PA a středně zatěžujících aktivit se u osob se $\mathrm{ZrP}$ dále promítá do celkového objemu všech vykazovaných aktivit. Chůze však má u osob se ZrP jiné parametry, časový objem věnovaný chůzi není podložen příslušnými daty o její skutečné realizaci v potřebném množství a to spíše odpovídá sedavému stylu života. Potvrzují to údaje z šetření pedometry a GPS zařízeními. Řešení se ukazuje ve zlepšení navigace, jistotě v lokomoci, přítomnosti trasérů a v další kultivaci povědomí o prospěšnosti tohoto typu lokomoce $\mathrm{k}$ udržení zdraví a tím i kvality života.

\section{LITERATURA}

Abu-Omar, K., \& Rütten, A. (2008). Relation of leisure time, occupational, domestic, and commuting physical activity to health indicators in Europe. Preventive Medicine, 47 (3), 319-323. 
Abu-Omar, K., Rütten, A., \& Robine, J. M. (2004). Self-rated health and physical activity in the European Union. Sozial- und Präventivmedizin, 49, 235-242.

Ainsworth, B. E., Haskell, W. L., Whitt, M. C., Irwin, M. L., Swartz, A. N., Strath, S. S., O’Brien, W. L., Bassett, D. R., Schmitz, K. H., Emplaincourt, P. O., Jacobs, D. R., \& Leon, A. S. (2000). Compendium of physical activities: An update of activity codes and MET intensities. Medicine \& Science in Sports \& Exercise, 33 (9), 498-516.

Bauman, A. E., Sallis, J. F., Dzewaltowski, D. A., \& Owen, N. (2002). Toward a better understanding of the influences on physical activity. American Journal of Preventive Medicine, 23 (2), 5-14.

Bláha, L. (2011). Vybrané studie $k$ uplatňování pohybových aktivit u osob se zrakovým postižením. Ústí nad Labem: Univerzita J. E. Purkyně.

Bláha, L., \& Cihlář, D. (2010). Uplatňování chůze u osob se zrakovým postižením. Aplikované pohybové aktivity v teorii a praxi, 2 (2), 3135 .

Blessing, D. L., McCrimmon, D., Stovall, J., \& Williford, H. N. (1993). The effects of regular exercise programs for visually impaired and sighted children. Journal of Visual Impairment \& Blindness, 87, 5052.

Hopkins, W. G., Gaeta, H., Thomas, A. C., \& Hill, P. M. (1987). Physical fitness of blind and sighted children. European Journal of Applied Physiology, 56, 69-73.

Houwen, S. Hartman, E. \& Visscher, C. (2009). Physical activity and motor skills in children with and without visual imairments. Medicine \& Science in Sports \& Exercise, 41 (1), 103-109.

Janečka, Z. (2003). Motorická kompetence zrakově postižených prepubescentů a pubescentů. In L. Dobrý \& O. Souček (Eds.), Pedagogická kinantropologie 2003 (pp. 115-131). Praha: Karolinum.

Leverenz, L. J. (2009). Visual impairment. In J. L. Durstine, G. E. Moore, P. L. Painter, \& S. O. Roberts (Eds.), ACSM's exercise management for persons with chronic diseases and disabilities (pp. 392-395). Champaing, IL: Human Kinetics. 
Lieberman, L. J., Stuart, M. E., Hand, K. \& Robinson, B. (2006). An investigation of the motivational effects of talking pedometers among children with visual impairments and deaf-blindness. Journal of Visual Impairment \& Blindness, 100, 726-736.

Lieberman, L. J., \& McHugh, E. (2001). Health-related fitness of children who are visually impaired. Journal of Visual Impairment \& Blindness, 91, 272-287.

Mikoláš, J. (2013). Specifikace chodeckých aktivit u osob se zrakovým postižením. Diplomová práce, Univerzita J. E. Purkyně, Pedagogická fakulta, Ústí nad Labem.

Nakamura, T. (1997). Quantitative analysis of gait in the visually impaired. Disability and Rehabilitation, 19, 194-197.

Short, F. X., \& Winnick, J. P. (1988). Adolescent physical fitness: a comparative study. Journal of Visual Impairment \& Blindness, 82, 237239.

Tudor-Locke, C., \& Myers, A. M. (2001). Methodological considerations for researchers and practitioners using pedometers to measure physical (ambulatory) activity. Research Quarterly for Exercise and Sport, 72 (1), 1-12.

\section{KONTAKT:}

doc. PaedDr. Ladislav Bláha, Ph.D., Ladislav.Blaha@ujep.cz 